\title{
Raccoon Eyes in Amyloidosis
}

"Atanu Chandra, ${ }^{1}$ Swarup K. Saha, ${ }^{2}$ Uddalak Chakraborty, ${ }^{2}$ Partha S. Karmakar, ${ }^{2}$ Goutam Biswas, ${ }^{2}$ Aritra K. Ray, ${ }^{2}$ Sukanta Dutta ${ }^{3}$

\section{عيون الراكون في الداء النشواني}

أتانو شاندرا، سواروب كانتا ساهـا، أودالاك تشاكرابورتي، بارثا ساراثي كارماكار، جوتام بيسواس، أريترا كومار راي، سوكانتا دوتا
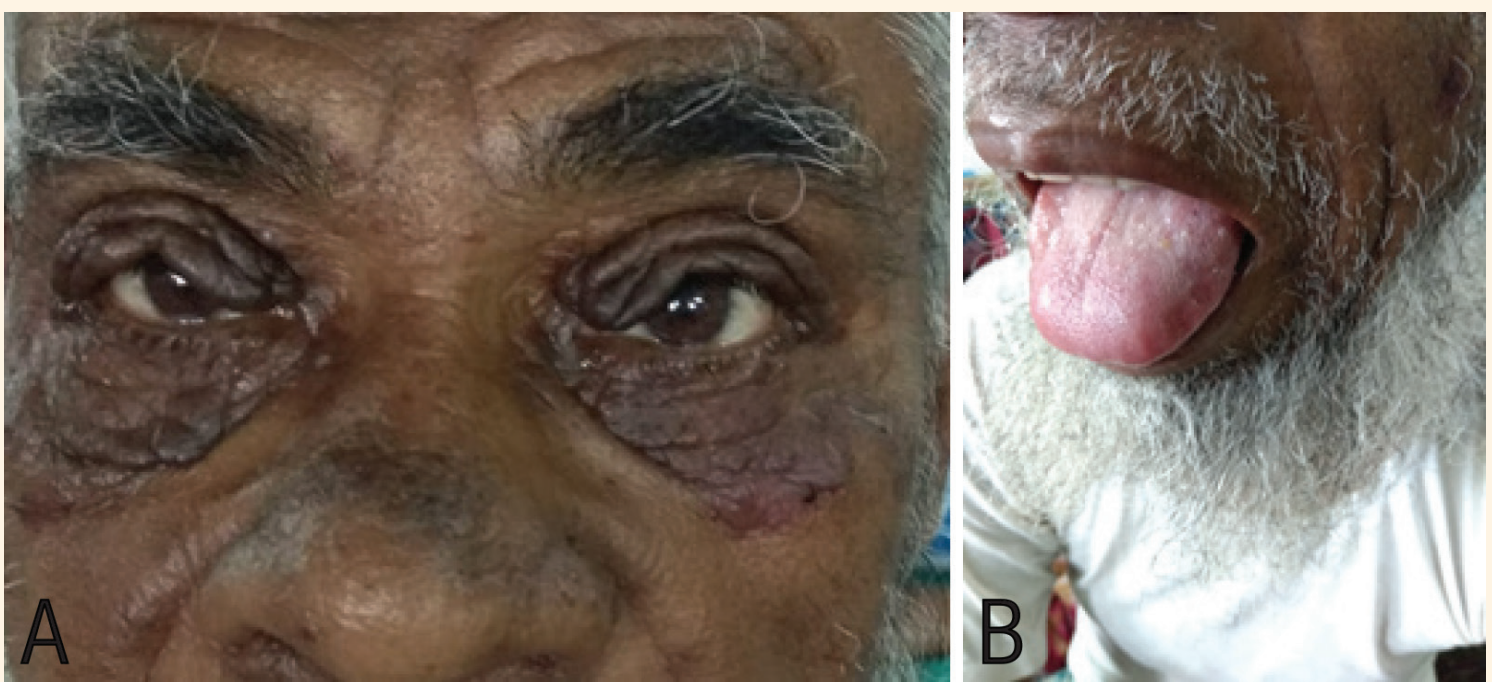

Figure 1: Photographs of the face of a 62-year-old male patient with amyloidosis showing (A) bilateral periorbital hyperpigmentations with skin folds ('raccoon eyes') and (B) macroglossia.

A 62-YEAR-OLD MALE PATIENT WAS ADMITTED to the Department of Internal Medicine, RG Kar Medical College, Kolkata, India, in 2018 with a history of gradually progressive shortness of breath on exertion for four months. He also complained of swelling of lower limbs, dry cough, weight loss and painless blackish discolouration of the eyelids. He did not have a history of hypertension or diabetes. There was also no history of trauma to the face or the head. Physical examination showed periorbital hyperpigmentation with skin folds ('raccoon eyes') and macroglossia [Figure 1]. There was bilateral pitting pedal oedema, elevated jugular venous pressure, diminished breath sound with a dull note on percussion in the lower zone of right lung suggestive of congestive cardiac failure with right-sided pleural effusion. Further evaluation of effusion with a thoracocentesis revealed a pleural effusion that was transudative in nature (pleural fluid protein $=0.3 \mathrm{~g} / \mathrm{dL}$, lactate dehydrogenase $=28 \mathrm{U} / \mathrm{L}$, white cell count $=18 / \mathrm{mm} 3)$. Urine studies revealed nephrotic range proteinuria (24-hour urine collection demonstrated excretion of 5.4 grams of protein). Antinuclear antibody and infectious screening were negative. Echocardiography showed concentric left ventricular hypertrophy and a sparkly appearance of myocardium with increased echogenicity [Figure 2A]. Strain echocardiography showed a cherry-on-top appearance [Figure 2B]. Abdominal fat pad biopsy was done and congo red stain was positive [Figure 3]. Serum protein electrophoresis showed a monoclonal spike of $3.66 \mathrm{~g} / \mathrm{dL}$ in the gamma fraction; urine electrophoresis was positive for Bence-Jones protein. Kappa free lightchains (FLC) were elevated at 1,020 mg/L (normal range: $3.3-19.4 \mathrm{mg} / \mathrm{L}$ ) with an elevated kappa/lambda FLC ratio of 56.6 (normal range: $0.26-1.75$ ). In light 

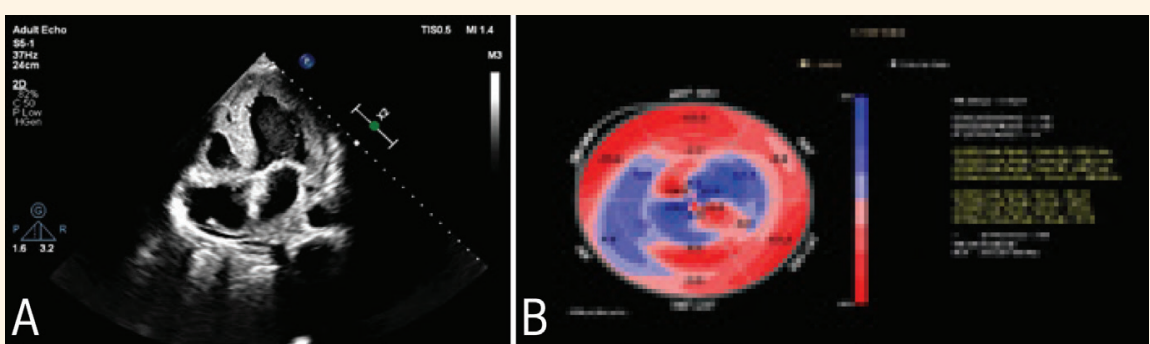

Figure 2: Echocardiography of a 62-year-old male patient showing (A) concentric left ventricular hypertrophy and sparkly appearance of myocardium with increased echogenicity and (B) strain echocardiography showing cherry-on-top appearance.

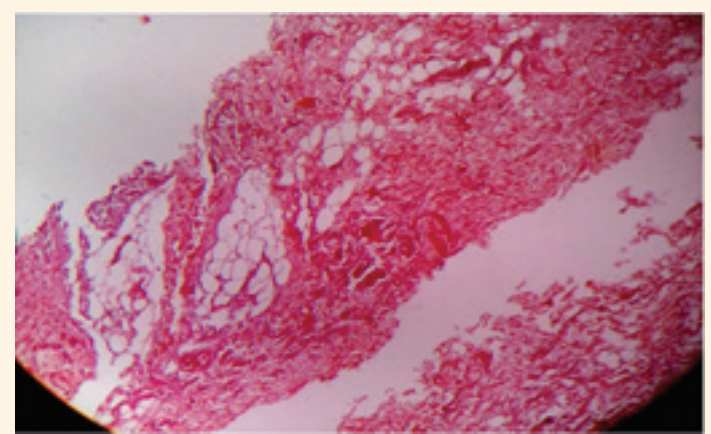

Figure 3: Positive Congored stain at x100 magnification showing abdominal fat pad biopsy indicative of the presence of amyloid fibrils.

of the clinical and immunohistological findings, a diagnosis of amyloid light chain (AL) amyloidosis was made. The patient was treated conservatively with diuretics and angiotensin converting enzyme inhibitors. His therapy was initially planned to be in the form of bortezomib, linalidomide and prednisolone. However, he was unfortunately lost to follow-up.

An informed written consent was obtained from the patient after full explanation regarding the publication of his images for academic interest. The patient did not have any objection regarding the use of his images which may reveal his identity and gave due permission to use them.

\section{Comment}

Amyloidosis consists of a group of disorders characterised by the extracellular deposition of insoluble protein polymers in different tissues and organs. ${ }^{1}$ AL amyloidosis, also known as primary systemic amyloidosis, is frequently caused by a clonal expansion of plasma cells that secrete a monoclonal immunoglobulin light chain depositing as amyloid fibrils in tissues. There is deposition of amyloid in different organs such as the kidney, gastrointestinal tract, autonomic nervous system and the heart. ${ }^{2}$ Early bruising, particularly around the eyes which is also known as 'raccoon eyes', is pathognomonic of this clonal plasma cell proliferative disorder. Other possible causes of 'raccoon eyes' are trauma and malignancies such as neuroblastoma and lymphoma. 'Raccoon eyes' occurs due to increased vascular fragility propagated by accumulation of amyloid fibrils.,

Kidneys are the most frequently involved organ and are seen in $70-80 \%$ of the patients followed by the heart (50-60\%). ${ }^{1}$ Macroglossia, a pathognomonic sign of this disorder, is seen in only $10 \%$ of patients. ${ }^{1}$ 'Raccoon eyes' is another uncommon but highly characteristic sign of AL amyloidosis. Although, 'raccoon eyes' are a very well-known manifestation of amyloidosis, the constellation of all these characteristic findings as were displayed by the current patient has been rarely reported in the literature.

Due to non-specific symptoms, diagnosis is often delayed until symptoms referable to a specific organ develop. As amyloidosis is a progressive disease often with fatal consequences, early and precise diagnosis is needed to prevent further organ damage. Clinicians should acquaint themselves with these specific clinical signs and with the importance of systemic evaluation to avoid delay in diagnosis.

\section{References}

1. Berk JL, Sanchorawala V. Amyloidosis. In: Jameson JL, Fauci A, Kasper D, Hauser S, Longo D, Loscalzo J. Harrison's Principles of Internal Medicine. 20thed.New York, New York, USA: McGraw-Hill Education, 2018. Pp. 803-9.

2. Merlini G, Seldin DC, Gertz MA. Amyloidosis: Pathogenesis and new therapeutic options. J Clin Oncol 2011;29:1924-33. https://doi.org/10.1200/JCO.2010.32.2271

3. PassosRda H, Pereira A, Neto AC, Ribeiro AF, Kutner J, Hamerschlak N,et al. Clinical image: Bilateral black eyes (raccoon's eyes) in AL amyloidosis. Arthritis Rheum 2006;54:3724. https://doi.org/10.1002/art.22184.

4. Pereira VG, Jacinto M, Santos J, de Abreu TT. Periorbital purpura (raccoon's eyes). BMJ Case Rep 2014;2014:bcr2013201407. https://doi.org/10.1136/bcr-2013-201407. 